MEI

II, vol. 6 nº 10

\title{
Ús de les xarxes socials a les biblioteques públiques municipals de la Xarxa de Lectura Pública Valenciana (XLPV)
}

\author{
Desamparados Cebolla Talens
}

Recibido el 13-07-2015

Aceptado en 13-07-2015

\section{Resum}

Es pretén realitzar una anàlisi descriptiva de les diferents xarxes socials utilitzades per les biblioteques públiques municipals i els motius pels qualsen fan ús. Amb aquesta investigació respondrem a preguntes com quines xarxes socials prefereixen utilitzar les biblioteques, els motius de l'elecció i per a què les utilitzen. Els resultats s'han obtingut a partir d'un qüestionari electrònic autoadministrat enviat a 371 biblioteques públiques municipals pertanyents a la Xarxa de Lectura Pública Valenciana (XLPV), de les quals han contestat 79. Els resultats d'aquest estudi quantitatiu mostren com el 59\% de biblioteques de la Xarxa de Lectura Pública Valenciana que han contestat no disposen de perfil a cap xarxa social i les que disposen de xarxa social prefereixen Facebook, Twitter o utilitzar una altra eina de la web social com és el blog. Entre els motius de l'elecció de la xarxa social hi ha el voler arribar a una gran quantitat d'usuaris i la instantaneïtat que caracteritzen les xarxes socials. Pel que fa a la utilització de les xarxes socials, entre les activitats per a les quals fan servir les xarxes socials figuren la de compartir informació de la biblioteca i la de difondre el seu fons.

\section{Paraules clau}

Xarxes socials, biblioteques públiques municipals, Xarxa de Lectura Pública Valenciana, web social, Facebook.

\section{Title}

Use ofsocial networksin the Public Libraries of the Valencian Public Reading Network(XLPV).

\begin{abstract}
This research tries to perform a descriptive analysis of the different social networks used by the Municipal Public Libraries and the reason for its use. With the mentioned investigation, we will be able to answer questions as how many social networks people prefer to use in the Libraries, the reason of their selection and the inducement to be used. The results have been obtained through an electronic questionnaire, self-administered, sent to 371 Municipal Public Libraries belonging to the Valencian Public Reading Network (XLPV), of which only answered 79. The results of this quantitative study show that $59 \%$ of the Libraries that take part of the Valencian Public Reading Network, which gave an answer, don't comply with the profile of any social network and those which have social network prefer to use Facebook, Twitter or another social tool as it is the blog. Two of the most important reasons to choose the social network is to achieve a big quantity of users and the instant way to get the information, both define social network. Regarding to the use of social networks, and the activities observed, it should be noted the information of the Library you can share and transmit its background.
\end{abstract}




\section{Keywords}

Social Networks, publiclibraries, social media, Xarxa de Lectura Pública Valenciana, Facebook.

\section{1.- INTRODUCCIÓ}

La investigació que es presenta està basada en el Treball de Fi de Grau titulat Biblioteques Públiques Municipals i noves fórmules de difusió: una anàlisi de les xarxes socials, defensat a la Universitat de València el 2014.

El tema del treball va ser proposat després de tenir certes experiències laborals a diferents Biblioteques Públiques Municipals (d'ara endavant BPM) i comprovar com Internet s'ha convertit en un recurs molt útil per a la difusió de la col·lecció de la biblioteca o de les seves activitats. Les noves tecnologies que permeten un ús interactiu i interconnectat comporten el preguntar-se què s'està fent a les BPM, com s'estan utilitzant els llocs de xarxes socials i si realment s'han convertit en una nova forma de difusió. Per això, el treball que es presenta s'ha centrat en l'estudi del nivell d'implantació de llocs de xarxes socials i la seva utilització com a noves eines de difusió a les BPM.

Per a realitzar la investigació, es plantejaren diferents mètodes, un qualitatiu amb entrevistes (arabé, es reduiria l'àrea d'actuació), o un quantitatiu, mitjançant un qüestionari remés a totes les biblioteques de la Xarxa de Lectura Pública Valenciana (XLPV). Finalment, s'optà per la segona opció, un qüestionari, anònim, per tal que respongueren les preguntes amb sinceritat.

Després d'analitzar les dades, s'arriba a conclusions sobre les xarxes socials més utilitzades i les raons per a la seva elecció, a més de conèixer el tipus de contingut publicat. Finalment, es realitza una proposta de millora dels perfils de les biblioteques a les xarxes socials, per tal que es converteixen en una vertadera eina de difusió i no en un simple taulell d'anuncis.

\subsection{L'ESTAT DE LA QÜESTIÓ}

A Espanya s'han publicat diferents treballs que analitzen la implantació de les tecnologies de la Web 2.0 a les biblioteques. La majoria se centren en una o diverses eines i en biblioteques universitàries. A continuació es comenta la bibliografia més destacable sobre aquest tema.

Primerament, com a bibliografia bàsica cal citarl'Informe APEIsobre web social (MARGAIX 2008) que resumeix i identifica les diferents eines de la Web 2.0.

Un dels primers articles que s'ha de comentar és "Bibliotecas 2.0 en España: el camino recorrido" (González Fernández-Villavicencio2007), presentat a unes jornades de la SEDIC, i en el que l'autora aposta per la formació, per a fer útils 
les eines de la Web 2.0, i per la planificació molt acurada, alimentada d'experimentació.

Altra publicació molt útil sobre el tema és la de Noemí Gómez Pereda i José Antonio Merlo-Vega, apareguda a la revista Educación y Biblioteca (2010). Es tracta d'un dossier on recopilen una sèrie d'exemples de totes les eines de la web social i com les han utilitzat en algunes biblioteques, a més d'oferir consells i idees per al seu ús.

Molt similar al treball que es presenta és la ponència realitzada al $\mathrm{V}$ Congrés de Biblioteques Públiques (2010) de Ballús Aragón, López Martínez i Toboso Vicente, en la qual presentaren un estudi sobre la presència de les biblioteques municipals de la província de Barcelona a les xarxes socials. El seu estudi es va realitzar mitjançant l'enviament d'un qüestionari autoadministrat electrònicament a les diferents biblioteques municipals de tota la província de Barcelona.

En relació a les biblioteques universitàries, trobem la publicació de Grande González i De la Fuente Redondo (2012), "Bibliotecasuniversitariasespañolas en la web social", treball on els autors utilitzen una metodologia basada en qüestionaris contestats voluntàriament pel personal de les biblioteques. Fan un estudi de les eines utilitzades, de les motivacions per a participar i les dades amb les quals aquestes s'inicien en les xarxes socials. Els autors estableixen una puntuació segons el nombre de serveis de social media oferts. En les seues dades, els serveis més estesos són els blogs i els llocs de xarxa social.

Entre altres treballs sobre biblioteques, en aquest cas nacionals, tenim el de Mar Buigues i Vicent Giménez (2012), "Impact of Web 2.0 on nationallibraries", on analitzen per continents, quantes biblioteques utilitzen cada lloc de xarxa social, a més d'oferir-nos una descripció de les diferents eines utilitzades a la Web 2.0, més completa que la que realitzaren Gómez Pereda i Merlo Vega (2010).

Finalment, cal citar l'article "La reputación corporativa de las bibliotecas en los medios sociales" (González 2013), on l'autora torna a remarcar la importància d'adaptació a les noves exigències de la societat i reinvenció de les biblioteques; aquestes han de definir què, com i on comunicar a Internet, han de conèixer les diferents eines tecnològiques disponibles i construir-se una identitat digital pròpia. A més, aconsella relacionar-se amb altres bibliotecaris que també estan presents a Internet per a generar una reputació digital.

De la bibliografia analitzada podem veure com els anys 2006-2007 foren els de l'aparició de tecnologies participatives, és a dir, les eines de la Web 2.0, i que foren adoptades per les biblioteques. A partir de llavors es produeix una 
expansió del seu ús per part de les biblioteques. Mentre en aquests últims dos anys les biblioteques universitàries han passat a formalitzar la seua presència a la web social i a començar una planificació a l'hora d'expandir-se, són moltes les BPM que comencen ara a aplicar les conclusions de Nieves González de 2007 i en les quals torna a incidir, en part, al 2013.

\subsection{TERMINOLOGIA}

Els termes Web 2.0, web social, xarxes socials, llocs de xarxa social o fins i tot social media (aquesta última accepció és la més moderna) són utilitzats quasi com a sinònims, però no ho són. A continuació s'analitzen els diferents termes.

\subsubsection{Web 2.0}

Es defineix com la confluència d'un conjunt de tecnologies que suposen un canvi en l'ús i la participació a la web. Encara que fou un terme encunyat per Dale Dougherty el 2004, va ser Tim O'Reilly qui va plantejar un conjunt de principis en els quals es basa la Web 2.0 al seu famós escrit "Qué es Web 2.0: patrones de diseño y modelos de negocio para la siguiente generación de software" que es poden resumir en:

1. Els usuaris consumeixen i creen contingut.

2. Creació de comunitats amb afinitats a través de xarxes socials.

3. La xarxa com a plataforma (depòsit d'informació, serveis i aplicacions en línia).

4. Les eines i serveis en línia són col·laboratius.

\subsubsection{Web social}

Com a alternativa a la Web 2.0 s'ha proposat el de web social, ja que es tracta d'un conjunt de serveis construïts per una gran massa d'usuaris actius. Hi ha una sèrie de eines i serveis associatsaaquesta web social. Es tracta de serveis que permeten als usuaris crear, editar, modificar o esborrar contingut de forma col-laborativa. Parlem de serveis per a emmagatzemar i compartir continguts, eines d'etiquetatge o tagging, serveis de valoració col·laborativa de productes o continguts, marcadors socials i, finalment, les conegudes xarxes socials.

\subsubsection{Les xarxes socials i els llocs de xarxa social: matisacions}

Són un dels diferents tipus de serveis associats a la web social, és a dir, formen part de la Web 2.0. Consisteixen en estructures socials, formades per un 
conjunt de persones que tenen una sèrie d'interessos en comú i si, a més, utilitzen la xarxa per a mantenir la relació, parlem de llocs de xarxa social. Els llocs de xarxa social són un servei basat en Internet que permet als seus usuaris construir un perfil públic o semipúblic dins d'un sistema delimitat i articular una llista d'usuaris amb els que comparteixen connexió, és a dir, permeten als usuaris interactuar basant-se en algun criteri d'afinitat. S'utilitzen indistintament les denominacions lloc de xarxa social i xarxa social; aquesta última denominació és la més estesa, de fet és el terme que s'ha utilitzat al qüestionari enviat a les biblioteques i el que s'ha fet servir al títol del treball.

Les característiques més important dels llocs de xarxa social són les següents:

- Interactivitat i instantaneïtat: s'intercanvia un gran volum d’informació i és de forma immediata, afavorit per la senzillesa d'accés que permeten els mòbils i les seves app.

- Personalització: l’usuari pot configurar el grau de privacitat.

- Multimedialitat: l'usuari pot aportar continguts en diferents formats com vídeo, imatges, àudio...

- Multiedició: els continguts poden ser modificats, comentats o contrastats per multitud d'individus i en temps real.

- Retroalimentació: la resposta immediata genera o afavoreix el debat i la interacció social.

Ara bé, també presenten canvis pel que fa a l'expressió escrita i presenten una sèrie de problemes amb la seguretat o la legalitat, entre d'altres.

\subsubsection{Social Media}

És el terme de més recent difusió. És definit com a plataformes de comunicació en línia on el contingut és creat pels propis usuaris mitjançant l'ús de les tecnologies de la Web 2.0, que faciliten l'edició, la publicació i l'intercanvi d'informació (Kaplan iHaenlein, 2010). Entre els social media més utilitzats estan les xarxes socials, els blogs i els miroblogs. 


\subsubsection{Eines de la Web 2.0}

A continuació es desgranen les eines més utilitzades a la Web 2.0 i es posen una sèrie d'exemples de cada tipus. La selecció que es presenta a continuació s'ha realitzat en base a les eines proposades a l'Informe APEI sobre web social.

\subsubsection{Llocs de xarxa social:}

- Facebook, https://www.facebook.com/, és un lloc de xarxa social lliure creat per Mark Zuckerberg. Ofereix serveis com el xat, un mural on veure l'activitat dels contactes, els quals es poden agrupar per treball, lloc o estudis acadèmics.

- Twitter, https://twitter.com/, és un servei de microblogging, és a dir, els tweets o missatges no poden superar els 140 caracters i, a més, són públics.

- LinkedIn, https://es.linkedin.com/, es tracta d'un lloc de xarxa social orientat al món laboral i dels negocis. Els perfils dels usuaris mostren el currículum vitae i, entre d'altres serveis, permet crear grups de discussió.

- Tuenti,https://www.tuenti.com/?m=Login, encara que ara és un operador de telefonia nacional, va nàixer com a lloc de xarxa social, ofereix serveis característics de lloc de xarxa social com perfil i missatgeria. En principi, va nàixer enfocat al públic adolescent espanyol.

- Google+,http://plus.google.com, és un servei de lloc de xarxa social associat a Google

- Inc. Compta amb un servei de xat anomenat Hangouts, a més de cercles, interessos i comunitats.

- Pinterest, http://www.pinterest.com/,és un lloc de xarxa social per a compartir imatges. Funciona amb taulells on els usuaris poden administrar les seves imatges per temàtica o hobbies.

- Altres llocs de xarxa social són MySpace, Ning, Xing. 


\subsubsection{Sindicació de continguts:}

RSS (Really Simple Syndication), s'utilitza per a difondre informació, actualitzada freqüentment, als usuaris subscrits a una font de continguts.

\subsubsection{Marcadors socials:}

Permeten guardar els enllaços que abans es guardaven com a marcadors al navegador, a més aquestos són categoritzats en un sistema d'etiquetatge anomenat folcsonomia, és a dir, assignar-los un tag o etiqueta. Un dels més utilitzats és Delicious, http://delicious.com.

\subsubsection{Imatges, fotografies i àudio:}

Flickr, www.flickr.com, és un lloc web gratuït que permet emmagatzemar, ordenar, cercar, vendre i compartir fotografies i vídeos en línia; a més, compta amb eines que permeten etiquetar les fotografies.

Picasa, http://picasa.google.com,és un lloc web per a compartir fotografies,actualmentadquirit i desenvolupat per Google.

\subsubsection{Vídeos:}

Youtube, https://www.youtube.com/, es tracta del lloc web més visitat pel que fa a vídeos,

els usuaris poden pujar i compartir vídeos, a més s'ha convertit en una gran plataforma publicitària.

\subsubsection{Blogs:}

Un blog és un lloc web que és periòdicament actualitzat on es publiquen textos o articles ordenats cronològicament. Hi ha diferents plataformes que ofereixen la possibilitat de crear un blog, els més coneguts són Blogger, http:/ / www.blogger.com, i WordPress, http://www.wordpress.com, que ofereix la possibilitat d'instal·lar-hiprogramari per afegir-hi noves funcionalitats. Ara bé, compten amb un fort competidor, Tumblr, https://www.tumblr.com/, una plataforma de microblogging que permet als usuaris publicar textos, imatges, vídeos o enllaços i afegir-los etiquetes. Nieves González (2007) afirma que els blogs s'han convertit en la major manifestació de la Web 2.0, de fet, ha sigut la eina més utilitzada per les biblioteques.

\subsubsection{Presentacions i publicacions:}

Slideshare, http://www.slideshare.net/?ss, es tracta d'un lloc web on els usuaris poden pujar i compartir presentacions, infografies, documents, vídeos, PDF i, fins i tot, webinars. Actualment pertany a LinkedIn.

Issuu, http://issuu.com, és un servei en línia que permet la visualització de material digitalitzat electrònicament, com ara números de revista o periòdics. 
El material que es puja es visualitza com una publicació impresa.

\subsubsection{Wikis:}

Wiki és un terme que prové del hawaià i significa ràpid. Es tracta d'un lloc web on les seves pàgines poden ser editades per múltiples voluntaris a través del navegador web. Els usuaris poden crear, modificar o eliminar un text que comparteixen.

\subsubsection{Els centres de lectura pública municipals}

De la mateixa manera que s'han realitzat una sèrie de matisacions sobre la terminologia referent a la Web 2.0, es considera necessari parlar de l'objecte de l'estudi, les biblioteques públiques municipals. Segons la Llei de Biblioteques de la Comunitat Valenciana, a l'article 3 del Títol I, es defineix les Biblioteques Públiques com a institucions creades per l'administració pública on es "conserven, gestionen, cataloguen, classifiquen i divulguen col·leccions o un conjunt organitzat de llibres, manuscrits, publicacions periòdiques o seriades, documentació gràfica, fotogràfica, fonogràfica, audiovisual i multimèdia i qualsevol altres materials, llibres electrònics o fonts d'informació fixada en qualsevol tipus de suport per a la consulta en sala o per mitjà de préstec personal o per a ser comunicada a través de xarxes tancades o obertes. La finalitat que té és contribuir, amb els mitjans tècnics i personals adequats, a l’obtenció de la informació i el desenvolupament de la investigació, l'educació i l'oci”.

La citada llei fa referència als centres de lectura pública municipal, estructurats en biblioteques centrals de xarxa urbana municipal, biblioteques públiques municipals, agències de lectura pública municipals i serveis bibliotecaris mòbils municipals. Ara bé, si ens referim a les biblioteques i agències de lectura la llei ens aconsella utilitzar l'expressió genèrica "centre bibliotecari” (article 3.5 del Títol I).

Encara que la llei marca la diferència entre biblioteques públiques municipals i agències de lectura (articles 25 i 26), diferència que radica en la població del municipi, les hores d'obertura del centre i el personal al seu servei, s'ha optat per generalitzar i utilitzar el terme biblioteca pública municipal al present treball, ja que les agències de lectura no deixen de ser institucions creades per l'administració pública, en aquest cas la local, amb els mateixos objectius, serveis i funcions que la biblioteca pública. 


\section{OBJECTIUS}

Els objectius d'aquesta investigació són els següents:

1. Analitzar la presència de les biblioteques públiques municipals als llocs de xarxa social.

2. Realitzar un rànquing dels llocs de xarxa social més utilitzades per les BPM.

3. Analitzar els usos que li donen als llocs de xarxa social.

4. Establir possibles xarxes de relació i col·laboració digital entre les biblioteques mitjançant els llocs de xarxa social.

Es realitza un estat de la qüestió a les biblioteques públiques municipals que formen la Xarxa de Lectura Pública Valenciana (XLPV).

\section{3.- METODOLOGIA}

La metodologia utilitzada per a l'obtenció de dades ha sigut quantitativa, ja que ha d'adaptar-se als objectius plantejats. Per a conèixer la presència de les BPM a les xarxes socials es requereix una metodologia quantitativa que ens permeta expressar les dades de forma numèrica i realitzar comparacions.

Les Biblioteques Públiques Municipals amb les que s'ha treballat han sigut les que conformen la Xarxa de Lectura Pública Valenciana. La Xarxa de Lectura Pública Valenciana està formada pels centres de lectura pública municipals integrats a la Xarxa de Biblioteques Públiques de la Comunitat Valenciana (Llei 4/2011) i per les biblioteques públiques provincials gestionades per la Generalitat Valenciana. Aquests centres bibliotecaris porten a terme un treball cooperatiu, tot realitzant i mantenint un catàleg col·lectiu dels fons en línia, amb un portal de serveis virtuals al ciutadà i un carnet de préstec únic.

Les BPM es varen identificar a partir del directori que ofereix la Subdirecció General del Llibre, Arxius i Biblioteques, http://dglab.cult.gva.es/Bibliotecas/ index_e.htm.

Els qüestionaris foren enviats a 156 BPM i 215 Agències de Lectura, en total 371 qüestionaris remesos als correus electrònics de les biblioteques amb un enllaç per a respondre'l tant en valencià com en castellà, dels quals sols s'obtingué resposta de 79 centres, això suposa una mostra del 20,75\%, menys 
d'una quarta part, és a dir, un índex de participació molt baix, però en sintonia amb els índex de resposta dels qüestionaris en línia que està al voltant del 30\%.

El procés va ser el següent:

1. Identificació de les BPM i Agències de Lectura. Es va procedir a cercar a XABIB, el directori de la Subdirecció General del Llibre, Arxius i Biblioteques, les BPM i les Agències de Lectura de les tres províncies: València, Castelló i Alacant. Els resultats es van exportar en un full de càlcul, evitant les repeticions, ja que moltes biblioteques conformaven una xarxa municipal o aportaven diferents direccions electròniques per a contactar.

2. Confecció del qüestionari. Es va escollir realitzar un qüestionari anònim amb l'aplicació Google Drive, ja que permet un treball en línia i l'exportació dels resultats en un full de càlcul. El qüestionari consta de 19 preguntes. Es va optar per realitzar un qüestionari anònim per a facilitar la sinceritat en algunes de les respostes, com per exemple pel que fa a l'ús dels llocs de xarxa social.

3. Enviament de l'enllaç del qüestionari amb una carta de presentació.

4. Confecció d'un full de càlcul on recollir els resultats.

5. Anàlisi i interpretació de les dades recollides.

La principal raó per a escollir un qüestionari electrònic autoadministrat és la raó econòmica, a la qual se li ha d'afegir la facilitat d'ús i la rapidesa. El gran inconvenient és la baixa resposta, tot i que es va procedir a reenviar el qüestionari. 


\section{RESULTATS}

Com s'ha comentat a la metodologia, foren enviats 371 qüestionaris, dels quals sols s'obtingué resposta de 79 centres.

De les respostes obtingudes, s'ha pogut comprovar com sols un $41 \%$, és a dir, 32 de les BPM que han contestat compten amb un lloc de xarxa social. A la figura 1 s'observa com, de les biblioteques que han contestat, són gairebé la meitat les BPM que no compten amb perfil a alguna xarxa social.

Figura 1: Presència a les xarxes socials

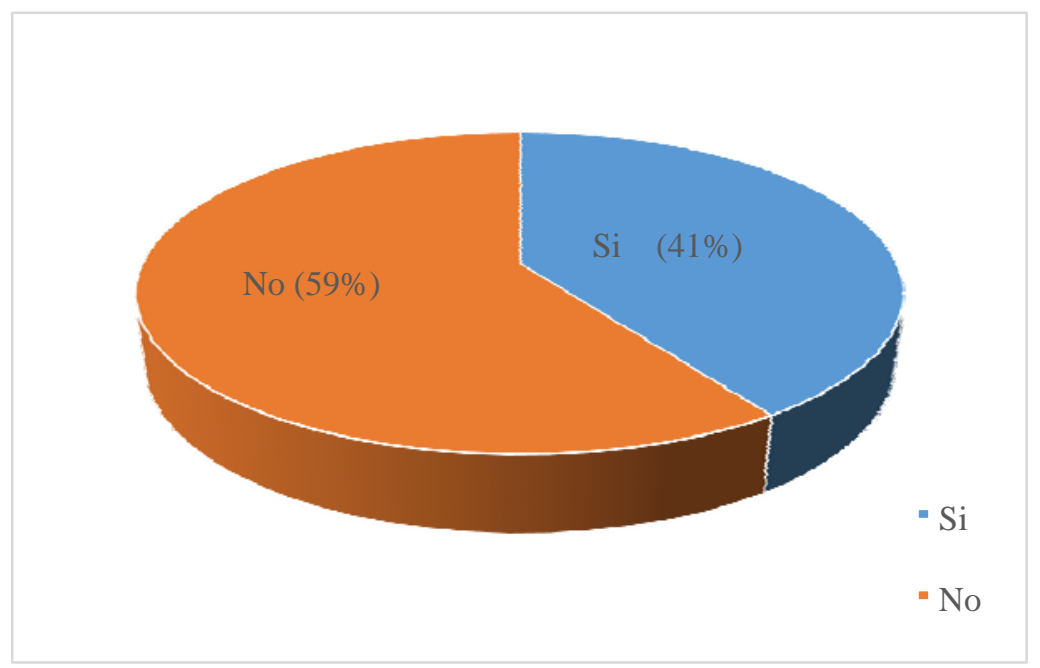

Les BPM que no compten amb xarxa social suposen el 59\% (47 BPM) restant de la mostra realitzada. A aquestes BPM se'ls va preguntar per una futura presència digital, un $45 \%$ han pensat utilitzar-nealguna i un $55 \%$ no s'ho han plantejat. La raó més esgrimida a l'hora de justificar la no utilització de les xarxes socials és la manca de recursos i/o personal, encara que també s'observa com entre les respostes hi ha un $17 \%$ de biblioteques que relacionen el no tenir perfil a les xarxes socials amb la institució de la qual depenen (l'Ajuntament), és a dir, són moltes les corporacions locals que no permeten als diferents serveis que l'integren disposar d'un perfil propi a les xarxes socials; com que les biblioteques entren dins dels serveis que presta la Corporació Local, se'ls està vetada la seua presència a les xarxes socials com a institució independent. La taula 1 permet observar les respostes obtingudes. 


\section{Motius pels que no s'utilitza cap xarxa social}

Manca de temps i/o personal

Preferim altres formes de comunicació amb els usuaris

No ens interessa

Altres (perfil institucional de l'Ajuntament)

No sabem com funcionen

\section{Respostes Percentatge}

$\begin{array}{rr}26 & 52 \% \\ 5 & 10 \% \\ 9 & 18 \% \\ 8 & 16 \% \\ 2 & 4 \%\end{array}$

Pel que fa a les biblioteques que sí compten amb xarxa social, les biblioteques donaren d'alta els seus perfils en un període que va des de 2008 a 2013. Va ser el 2007 quan Facebook va llançar la xarxa social en castellà, a partir d'aquesta data i en qüestió de 6 anys s'ha produït un boom pel que fa a la creació de noves xarxes socials com Tuenti (2006) o Twitter (2006), però també pel que fa a l'adopció d'aquestes per part de les biblioteques. A la figura 2 es visualitzen els resultats relacionats amb els anys de creació del perfil de les BPM a les xarxes socials .

Figura 2: Any de creació del perfil a les xarxes socials

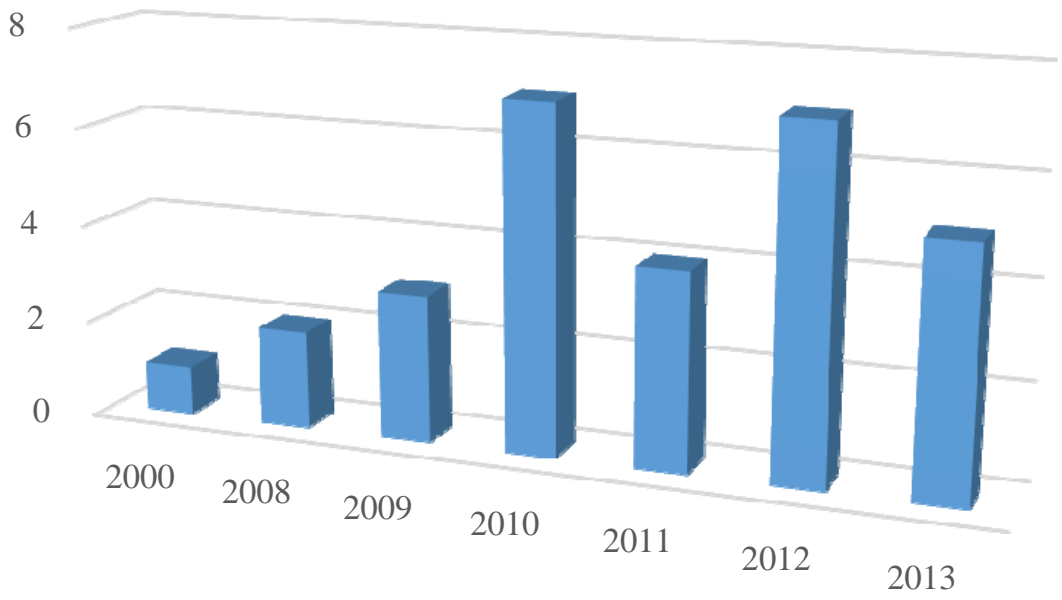


Si s'efectuara un rànquing de les eines de la Web 2.0 més utilitzades trobaríem que aquestes són Facebook, la publicació de continguts enblogs i en Twitter. L'objecte d'estudi són les xarxes socials. Ara bé, moltes BPM compten com a xarxa social el blog, donada la seva interacció amb els usuaris; per aquesta raó s'inclogué entre les possibles respostes algunes de les eines de la Web 2.0, cosa que va permetre comprovar com moltes de les biblioteques feien servir més d'una eina de la web social. A la taula 2 es poden veure les eines de la Web 2.0 ordenades segons el nombre de perfils de les biblioteques.

Taula 2. Ferramentes i nombre de perfils a les xarxes socials

\begin{tabular}{lc} 
Ferramentes & Perfils \\
\hline Facebook & 29 \\
Blog & 15 \\
Twitter & 12 \\
Flickr & 5 \\
Google+ & 5 \\
Pinterest & 5 \\
Youtube & 5 \\
Tuenti & 3 \\
LinkedIn & 2 \\
Slideshare & 2 \\
Issuu & 1 \\
\hline
\end{tabular}

Deu comentar-se també la quantitat d'eines utilitzades per les BPM; les biblioteques no sols utilitzen una eina de la Web 2.0, hi ha centres que tenen perfil en almenys 9 eines de la web social.

$\mathrm{Al}$ rànquing de la taula 2 es pot observar com les eines que queden entre les tres primeres posicions se situen Facebook, blog i Twitter. S'ha decidit agrupar aquestes tres eines per a poder analitzar el comportament de les BMP pel que fa a l'elecció de més d'una xarxa social i així s'observa que un $31 \%$ de les BMP tenen sols perfil a Facebook i un $6 \%$ sols tenen blog. Si s'analitza la presència a les xarxes socials, estrictament parlant, és a dir,Facebook o similars, són un $94 \%$ del $41 \%$ de les biblioteques que han contestat que si tenen perfil a les xarxes socials. A continuació s'exposen a la taula 3 els resultats de l'anàlisi, on es pot veure que sols hi ha dos biblioteques que no tenen cap tipus de perfil a xarxes socials, sols utilitzen el blog: 
MEI, II, Vol. 6, no 10 , pág. 18

Taula 3: Combinacions de perfils a xarxes socials

\begin{tabular}{lccc}
\cline { 1 - 1 } Combinacions de perfils a xarxes socials & & Nombre & Percentatge \\
Facebook & 10 & & $31 \%$ \\
Blog & 2 & $6 \%$ \\
Facebook i blog & 6 & $19 \%$ \\
Twitter i blog & 1 & $3 \%$ \\
Facebook i Twitter & 5 & $16 \%$ \\
Facebook, Twitter i blog & 6 & $19 \%$ \\
Facebook i altres xarxes socials & 2 & $6 \%$ \\
\hline Total & 32 & $100 \%$ \\
\hline
\end{tabular}

Les BPM prefereixen eines que es caracteritzen per la seva instantaneïtat i actualització, a més, en el cas de Facebook i Twitter es tracta de xarxes socials amb una gran quantitat d'usuaris. De fet, es preguntava a les BPM per l'elecció de la xarxa social, el 41\% de les BPM que respongueren, coincidien en que pretenien arribar a una gran quantitat de públic.

\section{Figura 3: Motius de l'elecció de la xarxa social}

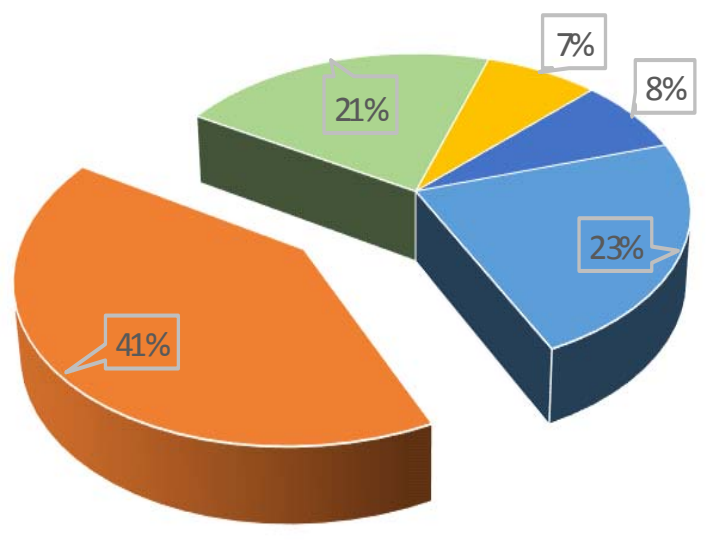

\footnotetext{
_. Facilitatd'ús (23\%)

- Granquantitatd' usuarisals quals es pot arribar (41\%)

- Instantaneïtat (21\%)

- Perfil personalitzable(7\%)
}

- Altres (8\%) 
S'ha agrupat a la variable "Altres", les respostes lliures que proporcionaren, com per exemple el tipus de públic al qual pretenien arribar, la no inversió en publicitat o que buscaven la interacció i la participació dels usuaris. Si es comparen aquestos resultats amb els que corresponen a l'elecció de la xarxa social, es veu com les BPM que compten amb blog han justificat la seva elecció en la facilitat d'ús d'aquest, i les que compten amb Facebook coincideixen en que busquen arribar a una gran quantitat de públic.

A la figura 2 ja s'ha avançat alguna cosa sobre l'any de creació dels perfils, ara s'analitzaran les BPM que sols tenen un perfil i les que han especificat l'any de creació de cada perfil, la resta de respostes han estat rebutjades per no ser fiables. Després d'analitzar el resultat, es pot dir que la majoria de les biblioteques que compten amb un únic perfil a una xarxa social el crearen entre $2011 \mathrm{i}$ 2013, i es tracta en un 80\% dels casos del lloc de xarxa social Facebook, on el perfil més antic data de 2009 segons les respostes facilitades. Pel que fa al blog, sols representa un 20\% i el més antic és de 2000.

Pel que fa a les BPM, es preguntà sobre la quantitat de seguidors que presentaven els seus perfils i la quantitat d'usuaris inscrits a la seua biblioteca per a poder comparar. Es decidí agrupar les biblioteques per nombre d'usuaris, establint 4 categories.

La majoria de biblioteques estan entre el rang de menys de 1000 usuaris i fins a 3000 usuaris. Si s'uneixen a aquests resultats els de la quantitat de perfils a les xarxes socials de les BPM, s'observa que les biblioteques amb més de 8000 usuaris solen tindre més d'un perfil a les xarxes socials i les biblioteques amb menys usuaris, menys de 3000 , tenen la majoria entre u i tres perfils a les xarxes socials. Com s'ha dit més amunt, les xarxes per les que opten les biblioteques amb menys usuaris són Facebook, Twitter i la publicació de continguts a un blog.

Taula 4: Relació usuaris de la biblioteca-quantitat de perfils

$\begin{array}{llll}\text { Biblioteques i usuaris } & 1 & 2-3 \text { perfils } & \text { Més de } 4 \text { perfils } \\ & \text { perfil }\end{array}$

\begin{tabular}{lcccc} 
Fins 1000 usuaris & 8 & 3 & 3 & 2 \\
Entre 1001 i 3000 usuaris & 10 & 4 & 5 & 1 \\
Entre 3001 i 8000 usuaris & 5 & 2 & 1 & 2 \\
Més de 8001 usuaris & 6 & 1 & 2 & 3 \\
No contesten & 3 & 2 & 1 & 0 \\
\hline Total & 32 & 12 & 12 & 8 \\
\hline
\end{tabular}


Pel que fa a si promocionen el perfil entre els usuaris físics, un $78 \%$ responen que sí el promocionen. També es preguntà per a què utilitzaven les xarxes socials. La majoria les utilitzen per a compartir informació sobre la pròpia biblioteca i les activitats que hi realitzen, a més de per a difondre el seu fons. Les que utilitzen Facebook, a més, fan servir la possibilitat d'enviar missatges i revisar l'activitat que fan els seus contactes.

Figura 4: Activitats que realitzen a les

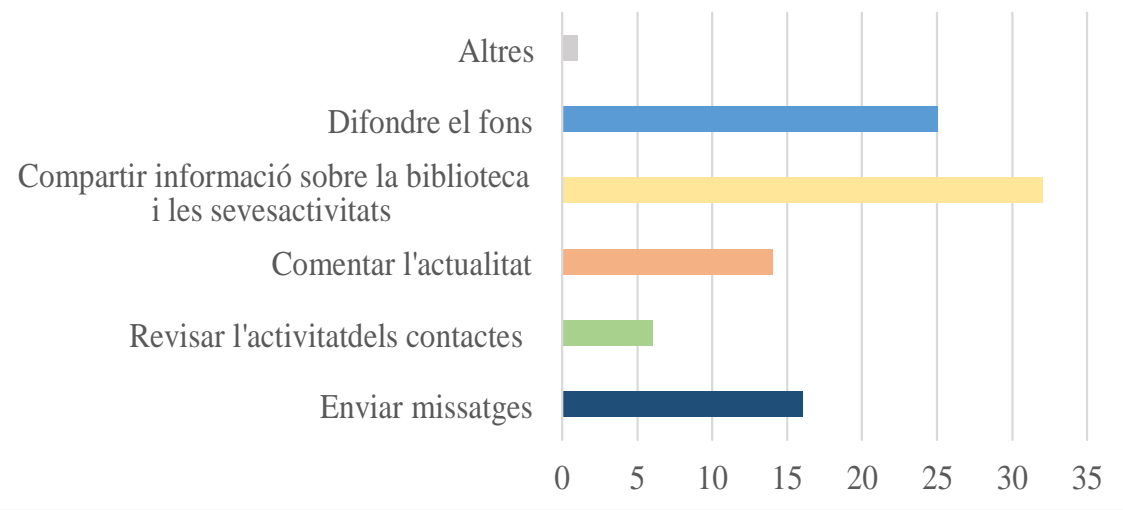

Sobre la freqüència amb la qual entren als perfils de les xarxes socials, s'observa com entren d'una vegada al dia a unes quantes vegades a la setmana, però són la majoria les que entren diverses vegades al dia i totes elles coincideixen en que utilitzen Facebook. Sols remarcar que la única biblioteca que entra a veure l'activitat menys d'una vegada al mes utilitza com a eina el blog.

Taula 5. Freqüència de consulta del perfil de les biblioteques a les xarxes socials

$\begin{array}{lr}1 \text { al dia } & 6 \\ \text { Diverses al dia } & 19 \\ 1 \text { a la setmana } & 1 \\ \text { Diverses a la setmana } & 4 \\ 1 \text { al mes } & 0 \\ \text { Diverses al mes } & 1 \\ \text { Menys d'una al mes } & 1 \\ \text { Total } & \underline{32}\end{array}$


Amb quina freqüència entreu al perfil de la biblioteca a ales xarxes socials? Aquests resultats s'han de posar en relació amb les respostes obtingudes a dos ítems més, com són les vegades en les que pugen contingut a la xarxa i per a què utilitzen les xarxes socials, ítem ja abordat a la figura 4. Primerament es compararen les vegades que entren a veure el perfil de la biblioteca a la xarxa social amb les activitats que realitzen, per a passar seguidament a comparar les vegades que consulten el perfil amb la freqüència de pujada de continguts a les xarxes socials.

Figura 5: Freqüència d'entrada al perfil i tipus d'activitat

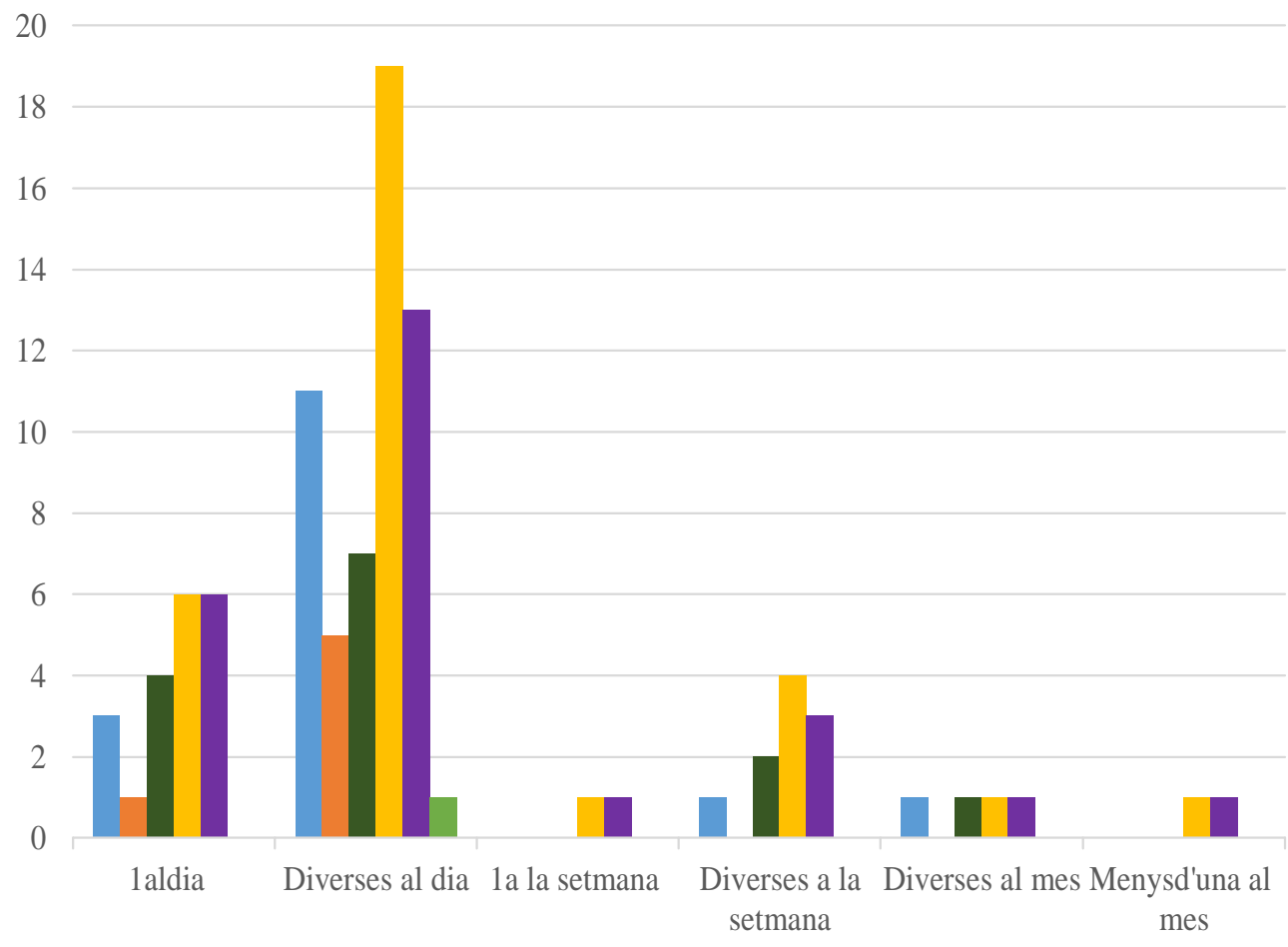

- Enviar missatges

- Revisar l'activitatdels contactes

- Comentar l'actualitat

- Compartir informació sobre la biblioteca i les sevesactivitats

- Difondre el fons

- Altres 
Com es pot observar a la figura 5 , les biblioteques que visiten el perfil de la biblioteca a la xarxa social més sovint, entre una i unes quantes vegades al dia, utilitzen la xarxa social per a enviar missatges, revisar l'actualitat que fan els seus contactes i comentar l'actualitat, a més de compartir informació sobre la pròpia biblioteca i difondre el seu fons. En canvi, les que visiten menys el perfil, solen revisar la missatgeria, comentar l'actualitat i aprofitar per a compartir informació de la biblioteca, de les seves activitats i difondre el seu fons.

Podria resultar interessant conèixer quantes vegades consulten el perfil de la biblioteca a la xarxa social i posar-ho en relació a les vegades que pugen contingut. Al gràfic s'observa com la majoria de biblioteques entren a veure el perfil de la biblioteca a les xarxes socials diverses vegades al dia, però sols pugen contingut unes quantes vegades a la setmana. Crida l'atenció la coincidència que es dóna entre la freqüència d'entrada al perfil i la de publicació de contingut a les biblioteques que entren almenys una vegada al dia a la xarxa social.

Figura 6: Comparativa entre visita al perfil i publicació de contingut

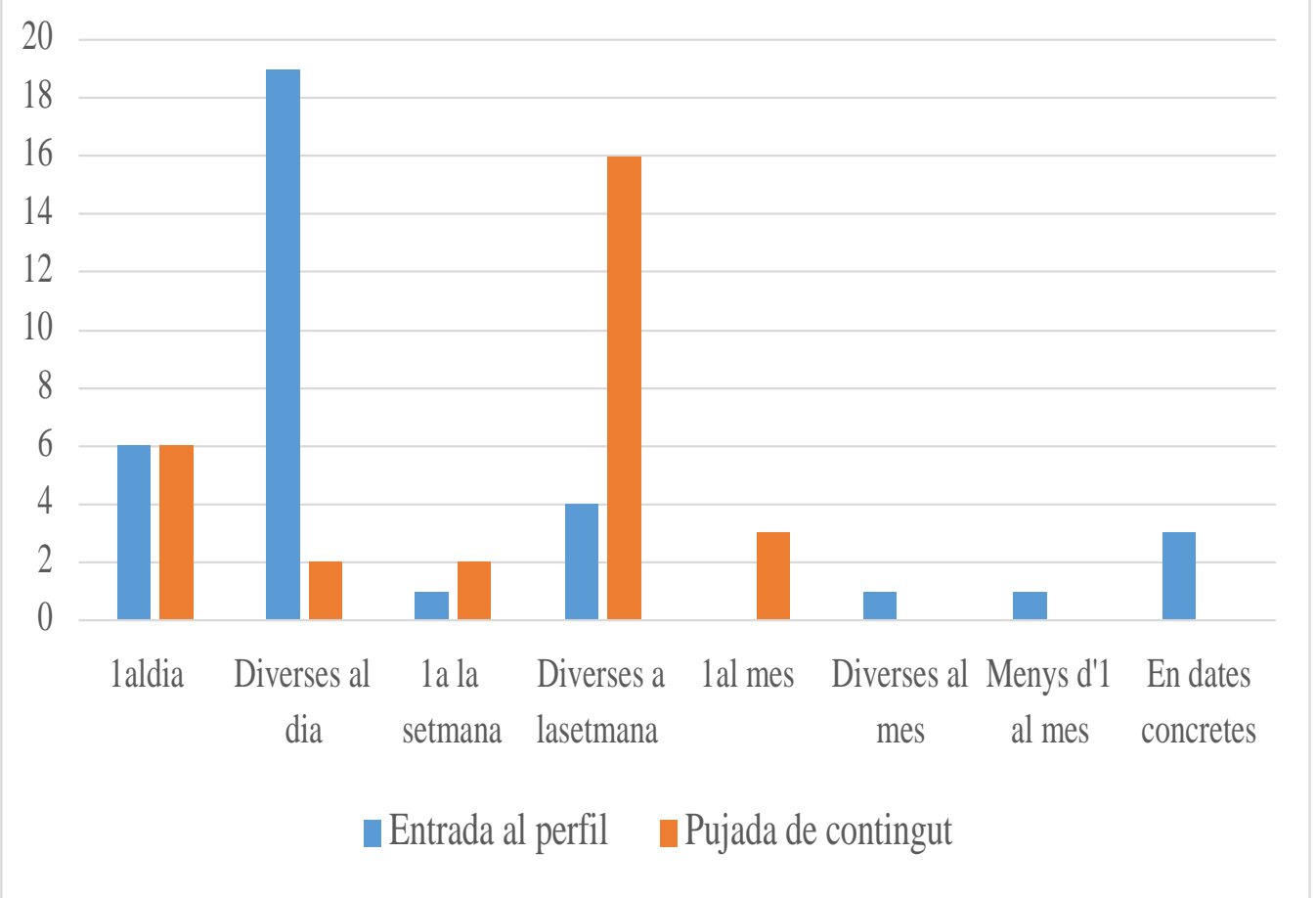


El que no es pot comparar són els resultats de la freqüència de pujada de contingut a la xarxa social amb el tipus d'activitat que realitzen, ja que utilitzar la xarxa social per a revisar l'activitat dels contactes, per exemple, no implica publicació.

Pel que fa al dinamisme del perfil de les biblioteques a les xarxes socials, el $81 \%$ de les respostes coincideixen en que sí són dinàmiques i faciliten la interacció amb els contactes, comentant i difonent publicacions. El 19\% restant opina que no tenen un perfil dinàmic. A la resta de biblioteques, 6 en concret, se'ls preguntà sobre què farien per a millorar eixa interacció amb els usuaris. De la possibilitat de respostes, 5 d'elles contestaren que hauriende publicar contingut amb més freqüència i, més exactament, publicar notícies actuals relacionades amb el món de la biblioteca; 3 respongueren que haurien de contestar als comentaris del seus contactes i sols dos consideraven que per a millorar la interacció podrien afegir contingut informal.

Per a verificar que les biblioteques tenien un perfil dinàmic, a eixe $81 \%$ de biblioteques que havien contestat que sí tenien un perfil dinàmic, se'ls preguntà si les seves publicacions a la xarxa social eren compartides pels usuaris, a la qual cosa contestaren afirmativament un $87 \%$; ara bé, de les 28 biblioteques que contestaren afirmativament, 9 no sabien contestar quantes publicacions tenien compartides i 12 no contestaren la pregunta, és a dir, un $75 \%$ no saberen contestar a la pregunta.

Continuant amb el tema del dinamisme de la xarxa social, a l'ítem 15 es preguntà si seguien a altres BPM a les xarxes socials i els resultats mostren com un $81 \%$ de les biblioteques síque segueixen a d'altres a les xarxes socials. Aquest ítem, relacionat amb el seguiment d'altres biblioteques a les xarxes socials, va ser subdividit per a intentar establir possibles relacions de col·laboració entre BPM. Als resultats obtinguts s'observa que les biblioteques segueixen de mitjana a unes 12 biblioteques a les xarxes socials, entre les més anomenades figuren les BPM d'Ontinyent, Cocentaina, Silla i les de la ciutat de València, a més de la Biblioteca Nacional de España.

De les 26 biblioteques que contestaren que sí que segueixen a altres BPM a les xarxes socials, sols la meitat comparteixen publicacions amb les biblioteques a les què segueixen; entre el contingut que comparteixen destaquen les activitats d'animació lectora i la informació professional, com es pot veure a la següent figura. 
Figura 7: Classe de contingut compartit amb altres biblioteques.

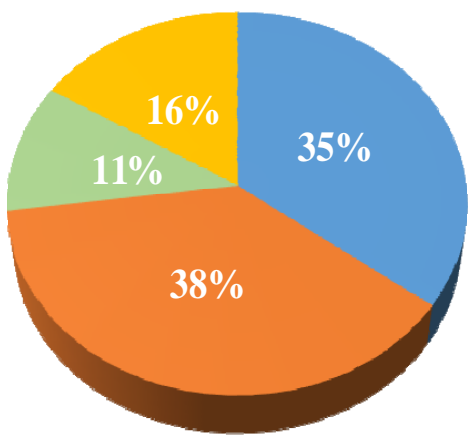

- Informació

Profesional (35\%)

Animació lectora (38\%)

Continguts Informals (11\%)

Informació d'actualitat (16\%)

Pel que fa a l'últim bloc de preguntes al qüestionari, es deixaren els ítems que es consideraven relacionats amb possibles valoracions personals. Els resultats obtinguts han estat els següents: el 50\% de les BPM valora que no ha augmentat el nombre d'usuaris físics a la biblioteca, en canvi, un $67 \%$ percep que si ha augmentat l'assistència a les activitats realitzades a la Biblioteca des que compten amb perfil a les xarxes socials i, en general, les BPM tenen una bona opinió dels resultats obtinguts gràcies a la utilització dels xarxes socials, ja que un $81 \%$ creu que la biblioteca ha millorat gràcies a la seva presència a les xarxes socials. Finalment, sols el 59\% de les biblioteques que han contestat el qüestionari reconeixen que no trauen profit a totes les possibilitats que ofereixen les xarxes socials.

\section{PROPOSTA DE MILLORA DEL PERFIL A LA XARXA SOCIAL}

La presència de les BPM a les xarxes socials ve donada en la seua majoria per l'anhel d'arribar a una gran quantitat de població, per a difondre així millor les activitats que es realitzen a la biblioteca, a més del seu fons. Ara bé, com diu González Fernández-Villavicencio (2007), fa falta una acurada planificació i no llançar-se sense pensar als braços de les xarxes socials. A banda, s'ha de pensar que l'èxit a les xarxes socials és un treball llarg i constant, crear un perfil a una xarxa social no implica un èxit immediat. Es pot intentar establir una sèrie de criteris per a obtenir l'èxit a les xarxes socials, però, es tractaria d'una tasca individual, ja que cada BPM és un món; a més, caldria analitzar la promoció 
que s'ha fet del perfil de la BPM a la xarxa social, com s'ha treballat el perfil, el contingut compartit i la qualitat de la informació compartida. Des d'ací es proposa un decàleg de pautes per a intentar millorar la presència de les BPM a les xarxes socials:

1. Veure quins són els objectius de la biblioteca.

2. Analitzar que es pretén amb la presència de la biblioteca a la xarxa social.

3. Conèixer/investigar les diferents xarxes socials.

4. Escollir la xarxa social més adequada d'acord als objectius de la biblioteca i les necessitats dels seus usuaris.

5. Donat que les xarxes socials preferides per les BPM són aquelles considerades poc professionals, és a dir, Facebook i Twitter, es proposa que els continguts oferts als perfils de les xarxes socials de les BPM siguen actuals, interessants, entretinguts, és a dir, el que esperen els usuaris d'una xarxa social no professional.

6. Tenir un perfil de la BPM a la xarxa social dinàmic, incentivar la comunicació amb els seguidors, respondre als seus comentaris o, fins i tot, comentar algun dels posts que realitzen els usuaris. Actualització constant.

7. Relacionat amb el punt 2: facilitar respostes i informació ràpida als usuaris/contactes/seguidors.

8. No cal deixar de banda la professionalitat, sols acostar-se un poc més al seguidor i deixar de banda l'argot del bibliotecari. Internet, més concretament les xarxes socials, estan convertint -se en un canal molt important per a la difusió de la imatge de la biblioteca pública municipal, i dels seus serveis, de vegades desconeguts per a la població.

9. Mantenir una xarxa de contactes amb altres BPM, seguir els seus perfils, compartir publicacions, comentar els posts.

10. Feedback o retroalimentació mitjançant l'anàlisi de les estadístiques, publicacions compartides o simplement veure què diuen a la xarxa social sobre la nostra biblioteca. 
Les xarxes socials poden ser un valor afegit i proporcionar més prestigi a la BPM si és gestionen correctament i no sols les utilitzen com a taulell d'anuncis. Informació que hauria de tenir el perfil de la BPM a la xarxa social:

- Informació general de la BPM: horaris i condicions d'accés

- Enllaços al catàleg en línia

- Presentació atractiva

- Actualització periòdica, almenys una vegada al dia.

- Estructura senzilla i clara dels continguts

- Continguts actuals, sobre la pròpia biblioteca i les activitats que realitza, però també sobre l'actualitat nacional i internacional, informació sobre eines útils per als usuaris o entreteniment, per exemple novetats literàries, enllaços a pàgines web, enllaços a presentacions o tutorials sobre com s'utilitzen certes eines de la web.

Les xarxes socials són un mitjà de comunicació idoni per a difondre els serveis de la biblioteca amb rapidesa i facilitat, a més de fer que arriben a una gran quantitat de gent. El següent pas a donar, per part de les biblioteques interessades en traure profit a les possibilitats de les xarxes socials, seria l'elaboració de polítiques i guies d'ús i estil i una avaluació continuada dels resultats, centrats en l'anàlisi de mètriques proporcionades per l'anàlisi de continguts compartits, comentaris realitzats o seguidors, en aquest sentit, Facebook permet la possibilitat d'estadístiques amb la creació de la pàgina de fans, i no amb el simple perfil, molt important per a realitzar posteriors avaluacions i millorar el servei ofert, un major posicionament a la web o fòrums.

\section{CONCLUSIÓ}

Després d'haver analitzar les xifres obtingudes arran del qüestionari realitzat, tot i la baixa participació, es pot concloure que les xarxes socials no han sigut implantades en general a les BPM de la Xarxa de Lectura Valenciana. Ara bé, es pot afirmar que,malgrat les poques biblioteques que utilitzen les xarxes socials, sí que s'ha trobat en la web social una nova eina per a la difusió del fons de la biblioteca i les seves activitats entre una gran quantitat d'usuaris. Usuaris que són potencials en gran mesura, ja que el caràcter públic de les xarxes 
socials i la no barrera física que comporta Internet, fan que no sols siguen els usuaris reals de la biblioteca els que apareguen com a seguidors o contactes de les BPM a les xarxes socials, sinó que també qualsevol membre d'una xarxa social pot fer-se'n seguidor.

Gràcies a les dades obtingudes, es pot afirmar que la xarxa social més utilitzada és Facebook, seguida per Twitter, és a dir, les BPM prefereixen eines que es caracteritzen per la seva instantaneïtat i actualització. Si es generalitza i parlem d'eines de la Web 2.0 es pot afirmar que les eines de la web social més utilitzades per les biblioteques són les xarxes socials (Facebook en concret) i el blog.

La presència als llocs de xarxa social de les BPM s'ha donat sense cap mena de planificació, a més, hauriend'aprendre a utilitzar correctament les xarxes socials en les que tenen perfil, ja que encara que als resultats s'observa com gairebé la meitat de les biblioteques creuen que si trauen profit de totes les possibilitats de la xarxa social. Ara bé, el que és cert és que moltes no saben distingir entre un perfil i una pàgina de fans o no saben comptabilitzar les publicacions que són compartides a la xarxa social.

La biblioteca had'adaptar-se als temps actuals i les xarxes socials es presenten com una eina molt interessant per a tenir en compte, les BPM haurien d'utilitzar les xarxes socials com a estratègia de màrqueting, per a aconseguir major difusió de les activitats, però també per a acostar-se als usuaris reals $\mathrm{i}$ aconseguir que els usuaris potencials que desconeixen la biblioteca s'acosten a descobrir-la, ja que és un servei públic, bàsic per a la formació i creixement de la ciutadania, com diu la UNESCO. La biblioteca ha d'estar on estan els usuaris (Ballús 2010). És bàsic escollir la xarxa social més adequada i no llançar-se de cap sense planificació, una xarxa social pot convertir-se en una eina per a portar a terme un programa de màrqueting de la $\mathrm{BPM}$, un canal per a difondre els serveis i saber de primera mà les inquietuds, necessitats, etc. dels usuaris. És un mitjà senzill, barat, ràpid i còmode per a conèixer els gustos dels usuaris. A més, amb el perfil a les xarxes socials, la BPM es crea una reputació digital que ajudarà a millorar la imatge pública de la biblioteca i que pot repercutir en una opinió pública favorable.

\section{BIBLIOGRAFIA}

ARROYO VÀZQUEZ, N., 2009. Uso profesional de las redes [en línia]. Anuario Think EPI, 3, 145-152. [Consulta: 9 abril 2014]. Disponible en: http://www.thinkepi.net/eluso-profesional-de-las-redes-sociales.ISSN 1886-6344 
BALlús ARAGÓN, A., LÓPEZ MARTíneZ, A. i TOBOSO VICENTE, A., 2010. Visibilidad de la Red de Bibliotecas Municipales de la provincia de Barcelona en las redes sociales [en línia]. En: V Congreso Nacional de Bibliotecas Públicas. 3-5 novembre. Gijón: Subdirección General de Coordinación Bibliotecaria. 11 p. [Consulta: 25 març 2014]. Disponible en: http://hdl.handle.net/10421/4905.

BRÖLL NADAL, A., CABRÉ-SERRA, A. i GÁNDARA-SANZ, D.,2012. Comunicar en la web: estrategias de Biblioteques de Barcelona. El Profesional de la Información,2 1(4), 406-412. ISSN 1386-6710.doi: 10.3145/epi.2012.jul.13

BUIGUES GARCÍA, M. i GIMÉNEZ CHORNET, V., 2012. Impact of Web 2.0 on national libraries [en línia]. International Journal of Information Management, 32. [Consulta: 3 abril 2014]. Disponible en:http://hdl.handle.net/10251/36999.ISSN 02684012

GARCÍA GIMÉNEZ, D., 2010. Xarxes socials: possibilitats de Facebook per a les biblioteques públiques [en línia]. BiD: textos universitaris de biblioteconomia i documentació, 24. [Consulta 10 març 2014]. Disponible en: http://bid.ub.edu/24/ garcia 1.htm. ISSN 1575-5886

GENERALITAT VALENCIANA, 2011. Llei 4/2011, de 23 de març, de la Generalitat, de biblioteques de la Comunitat Valenciana[en línia].DOCV núm. 6488. 25 març 2011. [Consulta: 22 febrer 2014] Disponible en: http://bv.gva.es/documentos/ley4.pdf

GÓMEZ PEREDA, N. i MERLO VEGA, J. A., 2010. Experiencias bibliotecarias con las tecnologíassociales [en línia]. Educación y Biblioteca, 177. [Consulta 8 Abril 2014]. Disponible en: http://www.baratz.es/portals/o/noticias/Dossier\%20Educaci\%C3\% B3n\%20y\%20Bibli oteca.pdfISSN 02 14-7491

GONZÁLEZ FERNÁNDEZ-VILLAVICENCIO, N., 2007. Bibliotecas 2.0 en España: el camino recorrido [en línia]. Boletín de la Sociedad Andaluza de Bibliotecarios, 86-87. [Consulta: 15 març 2014]. Disponible en: dialnet.unirioja.es/descarga/ articulo/2544094.pdfISSN 2253-6108

GONZÁLEZ FERNÁNDEZ-VILLAVICENCIO, N., 2013. La reputación corporativa de las bibliotecas en los mediossociales [en línia]. Item: Revista de biblioteconomia i documentació, 57. [Consulta: 15 març 2014]. Disponible en: http:// hdl.handle.net/10760/20546ISSN 02 14-0349

HERRERA MORILLAS, J. L.i CASTILlO DÍAZ, A., 2011. Bibliotecas universitarias 2.0: el caso de España. InvestigaciónBibliotecológica, 25(55), 175-200. ISSN 0187-358X MARGAIX ARNAL, D., 2008. Informe APEI sobre web social[en línia]. Gijón: APEI, AsociaciónProfesional de Especialistas en Información. [Consulta: 22 febrer 2014]. Disponible en: http://libros.metabiblioteca.org/handle/001/187

MERLO VEGA, J. A., 2011. Cuando el pasado es el presente y el presente es el futuro. En:Biblioblog [en línia]. 17 abril 2011. [Consulta: 25 març 2014]. Disponible en: http://biblioblog.org/2011/04/17/cuando-el-pasado-es-el-presente-y-el-presente-es

TORRES SALINAS, D.,2010. Web 2.0 y biblioteca: de la experimentación a la evaluación[en línia]. En: V Congreso Nacional de Bibliotecas Públicas. 3-5 novembre. Gijón: Subdirección General de CoordinaciónBibliotecaria. 8 p. [Consulta: 25 març 2014]. Disponible en: http://hdl.handle.net/10421/4973 